\title{
Coaching, assessment and teachers' performance in implementing teaching method of Islamic education of elementary school in Magelang
}

\author{
Nur Solikhah \\ SDIT Ihsanul Fikri Kota Magelang \\ nur_solikhah09@yahoo.co.id \\ DOI: 10.18326/mudarrisa.v10i1.25-46
}

\begin{abstract}
Related to teacher performance, coaching and assessment are activities continuously carried out by supervisors. This study aims to determine the coaching and assessment conducted by supervisors, and to discover teachers' performance in implementing teaching method used by Islamic Education teachers of Elementary school in Kota Magelang. Using descriptive qualitative research approach, this study was a field research by involving 3 supervisors and 35 Islamic Education teachers of Elementary School in Kota Magelang. The results of this study indicated: (1) Coaching to teachers of Islamic Education of Elementary School conducted by supervisors has been carried out with appropriate steps and with designing programs in advance which regularly applied through activities of Teachers Working Group (KKG); (2) Assessment to Islamic Education Teachers of Elementary School in Kota Magelang performed by supervisors shall be conducted through regular academic supervision once a semester in accordance with the standards decreed by the government; (3) Islamic Education teachers performance of Elementary School has applied various teaching methods, including Make A Match, Peer Tutor, Knowledge Shop, Problem Solving, Quis Jeopardi, Roll Play, Talking Stick, Mind Map, Number Together, Crossword Puzzle, Interactif Lecture, Jigsaw, and Shortcard.
\end{abstract}

Keywords: coaching, assessment, supervisors, Islamic Education, teachers' performance 


\section{INTRODUCTION}

Since teachers as educators need to have wide knowledge, teacher professional coaching is an important issue related to the improvement of teachers' ability in teaching and learning activies. Mulyasa (2006: 21) argues that teachers' duty is not only limited on delivering information to learners, but also on having ability to understand learners along their uniqueness in order to be able to assist them in facing learning difficulties. Therefore, teachers are required to comprehend various effective and appropriate learning models in order to guide learners optimally.

Teachers have an important role in education, yet in Indonesian society their duty are still limited till now. Moreover, it is not easy for school supervisors to get the data and observe the reality of teachers' daily performance in front of their learners. Though class visit program conducted by supervisor cannot be rejected, teachers try to show their best in planning and implementing teaching and learning process when they are being supervised. They will go back to work as usual, sometimes without preparation and motivation. Therefore, the supervisors need to conduct regular teacher performance assessment as it needs special attention from the supervisors. According to Tutik Rachmawati (2013: 101), teacher performance assessment is one of the competencies required to be mastered by the supervisors. It is part of the education evaluation competences. Implementing teacher performance assessment is intended not to complicate the teachers, but to achieve a professional teacher. Daryanto (2013: 195) states that teacher performance assessment is also 


\section{Mudarrisa: Jurnal Kajian Pendidikan Islam, Vol. 10, No. 1, 2018}

conducted to show appropriately about teachers' activities in the classroom, and to help teachers improve their knowledge, skills, as well as quality of learning.

One of education problems faced today is the weakness of learning process. Many factors determine learning process success, including teachers' quality in using media and teaching methods. Teachers' accuracy in using media and teaching method will affect student learning outcomes. If teachers can choose a learning medium that is appropriate to the learner characteristics, the learning outcomes will be more effective. Furthermore, the use of instructional media, especially images, will make it easier for learners to understand the material taught by the teacher. Suwardi et al (2017:3) argues that elementary school students who are at the age of children more easily understand something through images and pictures. Selecting instructional media is determined by the teaching method used by the teachers. Therefore, teachers need to apply appropriate teaching methods which in accordance with the learners' characteristics.

Ideally, the learning process should be encouraged to develop children's thinking skills. Wina Sanjaya (2010: 1) states that for Islamic Education, learners tend not to develop attitudes that are in accordance with religious norms as the learning process is only directed towards mastering and memorizing materials, indicating that Islamic Education learning process in schools still needs to be improved. Therefore, Islamic Education learning process has to be directed in order to develop attitudes towards the students in accordance with the proper and correct religious 


\section{Mudarrisa: Jurnal Kajian Pendidikan Islam, Vol. 10, No. 1, 2018}

norms and practices which needs teacher creativity in applying teaching method. As stated by Suwardi, et al (2017: 220), children cognitive development is affected by environmental conditions, experiences, and information they have.

Strengthening education quality in Indonesia should begin by improving elementary school education quality as it is the most basic level in education, therefore it affects on the next level education quality. In addition, elementary school is part of the nine-year compulsory education. Based on Government Regulation No. 47 of 2008 as the implementation of the mandate of the National Education System Act, the government has launched 9 years compulsory education consisting of elementary level for 6 years and junior high school / MTs for 3 years. It shows that strengthening the education quality in elementary schools has an important role in improving the education quality in Indonesia.

In the Minister of Education and Culture of the Republic of Indonesia no. 103 of 2014 on Learning in Primary and Secondary Education, article 2, paragraph 6, which states that the method of learning as referred to in paragraph (2) is a method or technique used by educators to handle a learning activity including lectures, questions, discussion. Therefore, teachers should master the various teaching methods and apply it in teaching and learning activities. In fact, there are still many teachers who have not applied varied teaching methods,

Most of the quality problems of elementary school institutions lies in the lack of professionalism of educators in conducting Teaching and 
Learning Activities (KBM) which gives an impact on the image and quality of education. KBM has a close relationship with supervision since supervision plays an important role in providing coaching / guidance, assessment, and direction to educators for improving teaching and learning process in order to become better and more professional. According to Suharsimi Arikunto and Lia Yuliana (2012: 290), supervision aims to improve quality and performance. With guidance and assistance, the professional qualities of teachers and institutions will always be maintained and enhanced. Here, the role of supervisor in managing education process occupies an important role. In the Regulation of the Minister of Administrative Reform (MENPAN) Number 21 of 2010 concerning the Functional Position of School Supervisor and Credit Score in Chapter II, Article 5 states that supervisor is one of the education personnel who plays a strategic role in improving the education quality since the supervisor, based on the principal task of supervisor, is conducting academic and managerial oversight tasks on the education unit including supervisory programming, implementation of supervision, monitoring of the implementation of 8 (eight) National Education Standards, assessment, guidance and professional training of Teachers, evaluation of the results of supervisory program implementation, and implementation of supervisory duties in special areas .

The decree of MENPAN Number 118/1996 in the framework of improving the quality of education states that it is necessary to have civil servants fully charged to supervise and educate at schools in the Ministry 
of Education and Culture, Ministry of Religious Affairs, and other departments. Furthermore, it is also mentioned in the MENPAN Decree Number 118/1996 Chapter I Article 1 point 1 that the school supervisor is a Civil Servant who is given full duty, responsibility and authority by the competent authority to supervise education at school by carrying out assessment and guidance of technical and administrative facets of preschool, basic and secondary education units. Therefore, in order to guarantee the improvement of the school education institution quality, it is necessary to continue the guidance with the supervisor's assessment of the teacher's performance as the guidance and assessment in an educational institution are needed to guarantee the quality (assurance) in accordance with the educational objectives. As coaching accompanied by good judgment will create professional teachers in the KBM, if the process of $\mathrm{KBM}$ implemented in a professional manner, it will produce a good learning achievement and then will produce a good graduate competence as well. The teachers' success in implementing teaching methods will affect students' learning outcomes and children's social behaviour. Dunt, Rabb, and Hanby (2017: 67) find out that learning approach is very influential on changes in social-emotional behavior according to the different characteristics of children's learning. It shows that the use of methods appropriate to the characteristics of children will make the learning activities more effective.

The result of interview with Poniman, S.Ag. as the chairman of Islamic Education Teachers Working Group (KKG) Magelang and Abdur 
Rochim S.Pd.I. as the head of KKG of North Magelang sub-district accompanied by the board and some teachers shows that supervion has been done regularly every month, but the teachers' performances assessment is still less. In coaching, supervisors discussed several times about teaching methods which can be applied by teachers in teaching and learning activities since supervisors think that there are still many teachers who are less creative in using the teaching method in the classroom. Based on the interviews, it is important to conduct research related to the implementation of supervisory duties and performance of Islamic Education teachers of elementary school in Kota Magelang in implementing the learning in the classroom.

\section{METHODS}

Belonged to field research, researcher used a qualitative research approach in which the researcher observed and participated directly in this study. Furthermore, this research used descriptive Naturalistic approach as this research was done in natural condition (natural setting). The data source was the natural situation as it was. Sugiyono (2014: 41) argues that the researcher is a key instrument who is able to dig the data by participant observation and interview.

Conducted on May $15^{\text {th }}$ - August $30^{\text {th }} 2017$, this study took location in all public and private schools in Kota Magelang. Using documentation, observation and interviews with participants as the data collection method, this qualitative research was case study research. Cresswell (2010: 261) 
argues that case study is a research strategy in which the researcher carefully investigates a program, event, activity, process, or group of individuals. The informants were three supervisors of Islamic Education teachers located in 3 subdistrics of Kota Magelang and elementary school teachers of Islamic Education in Kota Magelang. The informant as the data source was chosen purposively and was snowball sampling. According to Sugiyono (2014: 400), snowball sampling is the way of determining the informant as a source of data by selecting the informant as a source gradually. In the early stage, some people who had power and authority were selected as the person who would "open the door" wherever the researcher did the data collection. Therefore, the researcher interviewed 35 teachers consicting of 25 teachers who teach in state school and 10 private teachers (or caleed as wiyata) from 35 schools in Kota Magelang. The researcher interviewed teachers until the teacher who used varied teaching methods was found.

This research data implemented Miles and Huberman model cited by Sugiyono (2014: 41). The data analysis was done when data collection took place in certain period. When the informant was interviewed, the researcher did data analysis as well based on the answer given. The data analysis was done continuously till the data completed. 


\section{Mudarrisa: Jurnal Kajian Pendidikan Islam, Vol. 10, No. 1, 2018}

\section{DISCUSSION}

\section{Supervisors' Coaching towards Islamic Education Teachers}

The person who does supervisory activity is called a supervisor. According to Thomas and Starratt (1993: 31), "the job of supervisor is to provide assistance, support, and profesional development opportunities. Teacher respond to professional norms, and their performance becomes more expansive." Therefore, the supervisor's duty is to help teachers, organize coaching, provide support to teachers so that they are more professional at work. Supervisor's coaching towards Islamic education teachers of elementary school will make them able to carry out the learning tasks properly and correctly.

Supervisor in conducting coaching which based on the analysis of Annual Program (Program Tahunan), Semester Program (Program Semester), and Academic Activities Plan (Rencana Kegiatan Akademik) aims to coach, assess and monitor the activities and teachers' performance as well as assist teacher in developing the ability to manage learning process and utilize media for achieving learning objectives. This is revealed from the annual program of supervisor in which the implementation of academic supervision aims to cultivate improved learning quality, improve the teachers' ability in learning process, and enhance the students' achievement quality. Similarly, in measuring and providing teacher performance assessment, supervisor cultivates and presents findings as a material for coaching. Planning is essentially used as a reference in 


\section{Mudarrisa: Jurnal Kajian Pendidikan Islam, Vol. 10, No. 1, 2018}

conducting supervison for estimating or projecting what to do and how the result is.

Based on the interview with three supervisors, it is revealed that in conducting coaching to the teacher, the supervisor has made coaching program for teachers as stated in Annual Program, Semester Program, and Academic Activies Plan. Programs created by supervisor include managerial supervision for supervison academic teacher and administrative supervision for educational personnel. This supervisory program conducted by the supervisor is to find out the learning effectiveness done by teachers and owned by the school. This is in line with Arikunto and Yuliana (2012: 179) opinion that coaching is a business undertaken to promote and improve personnel quality, both educative and administrative, in school environment. The supervisor's answer confirms statement stated by Carl Glickman (2009: 8) that "supervision is the function in schools that draws together the discrete elements of instructional effectiveness into whole-school action”. Supervision done by the supervisor is an action to determine learning effectiveness conducted by teachers in schools. Supervisors have routinely run the program so that the program can run on target. The conducted coaching program and KKG are held simultaneouely and regularly every month.

In running the coaching program, there is a directional guidance pattern. The pattern done by the supervisor tends to apply the mentoring model which is situational, conditional, and using customized coaching materials, places, as well as facilities. It confirms Cansall (2016: 238) 
suggestions of effective models of teachers' professional proficiency development including mentoring models, applied science models, "from to practice" models, and inquiry models or reflective models which is explained: (1) Mentoring model is a model in which experienced one shares knowledge or does coaching on the less-experienced teacher; (2) applied science model is a combination of relevant research results with practical needs; (3) the inquiry model is a teacher-based approach in which teachers should also be a researcher to do activities such as reading, exchanging opinions, observing, analysing critically, and reflecting on their practical experience as well as improving it. Elementary School Teachers' coaching of Islamic Education in Kota Magelang in mastering teaching method is by inviting expert from province and empowering teachers who have followed training to convey knowledge gained from another teacher. This kind of coaching means using the inquiry model that is based on the teachers.

Coaching program routinely done by supervisors brings benefits for Islamic education teachers of elementary school in Kota Magelang. Teacher who has not mastered various teaching methods can comprehend and get some references in applying teaching methods. Supervisor need to provide guidance to Islamic education teacher of elementary school, especially related to the mastery and the use of teaching methods, in order to guide teacher to choose and use the method appropriately. It confirms Zepeda (2003: 1) statement that "supervisors are teachers of teachers-of adult professionals with learning needs as varied as those of students in 


\section{Mudarrisa: Jurnal Kajian Pendidikan Islam, Vol. 10, No. 1, 2018}

their classrooms". Therefore, the supervisor is a teachers' teacher who assist another teacher in improving the teachers' teaching ability in classroom.

After the Islamic Education supervisor of elementary school in Kota Magelang did coaching, the supervisor identified learning weaknesses of the teacher for improvement including what the cause was and whe they did not perform well. In practice, there are obstacles faced by supervisors including teachers who are still monotonous in teaching, teachers who think to teach only, and teachers who are still lack of ghiroh in achieving success, so they do not do to self-reflection when their students are failed. Based on that situation, a follow-up action such as coaching is done. According to Dadang Suhardan (2014: 36), coaching is a service to teachers in order to improve their performance. This indicates that the ultimate goal of supervisors is to improve the teachers' performance, especially in implementing teaching in classroom. If the supervisor can implement coaching properly, teachers' awareness in improving learning quality will be increased. Here, the supervisor's follow up duty is giving awareness. It is done by the supervisor when conducting coaching in teacher work grup activities (KKG). Each coaching is delivered to Islamic education teachers of elementary school for self evaluation. Self-evaluation is intended for teachers to improve programs, and policy. Moreover, there should be a good cooperation among Islamic education teachers, principal, and other subject-teachers. 


\section{Mudarrisa: Jurnal Kajian Pendidikan Islam, Vol. 10, No. 1, 2018}

\section{Supervisors' Assessment towards Teachers' Performance}

In general, supervisors have a duty of conducting an assessment towards teachers' performance. So do Islamic Education teachers of elementary school. Supervisors in conducting assessment of Islamic education teachers of elementary school in Kota Magelang Year 2017 are based on annual program analysis, semester program, and Academic Activity Plan. The result indicates that the teachers' supervisor of Islamic Education in Kota Magelang year 2017 has made and implemented an assessment program for teachers, principals, and school accreditation for measuring and giving performance assessment towards teachers and principals, and school accreditation for coaching. Teachers' supervisors of Islamic Education in Kota Magelang year Magelang also assess the implementation of performance assessment towards teachers, principals, and school accreditation. This result is processed and presented for Islamic Education supervisor of elementary school in Kota Magelang as a basis for improving teacher performance and principals, and school accreditation. Then, the supervisor makes follow-up plan aiming to improve the system of performance assessment towards teachers and principals, and school accreditation

Assessment conducted by the Islamic Education supervisor in Kota Magelang has been run regularly through teacher supervision, especially for certified teachers. The Islamic Education supervisor of elementary school statement is in line with the answer given by 32 teachers that Islamic education supervisor regularly conducted assessment through 
supervision; while the other 3 teachers said they did not do it regularly. Supervisors state that the assessment is done routinely every semester in the form of score given once a year by the supervisor for Islamic education teachers under the Ministry of Religious Affairs, and by the principals based on the report for Islamic education teachers under the Ministry of Education and Culture. This opinion was in line with the statement of 21 teachers, while 14 teachers stated that the assessment was done every 3 months. It confirms Hosnan (2016: 283) who argues that teacher performance assessment are conducted on a regular basis each year related to the overall competence of the teacher in performing their main duty.

Before conducting supervision to schools, based on the three supervisors' opinion, there was a prior notice. However, 18 teachers answered that there was not any prior notice, while 12 teachers said there was some notice, and the other 5 argued sometimes there was and sometimes there was not. It indicates the supervisors' inconsistency in informing the teachers prior to supervision. Supervisors tend not to notify the teacher in advance, called as sudden inspection (sidak). Based on the researcher's analysis, the supervisor only notified some teachers, especially senior teacher.

Islamic Education supervisor of elementary school in Kota Magelang in conducting assessment is by observing and direct monitoring to the teacher who is being supervised. This is in line with the Regulation of the Minister of Administrative Reform and Bureaucracy Reform (Permenneg PAN and RB) Number 16 of 2009 that the teacher performance 


\section{Mudarrisa: Jurnal Kajian Pendidikan Islam, Vol. 10, No. 1, 2018}

assessment is the assessment of each item of teacher main task in the framework of career development, rank, and position. Carried out through observation and monitoring, this assessment is an evidence-based assessment process undertaken in learning prosess. The teacher performance assessment indicators is conducted towards three classroom learning activities, namely: (1) The Planning of Learning Activities, (2) The Implementation of Learning Activities, (3) The Evaluation of Learning.

Since the supervision instrument has been standardized, the supervisor only follows the guideline. The determination referring to education national standard of Indonesia aims to guarantee the quality of national education for educating nation and shaping character and dignifying civilization. The scope of education national standard in Kota Magelang includes: (a) Content standards; (b) Process standards; (c) Graduate competence standards; (d) Educators and educational personnel standards; (e) facilities and infrastructure standards; (f) Management standards; (g) financing standards; and (h) Education assessment standards. The assessment used are the assessment of educator performance showing at least $90 \%$ achieving good criteria and the SNP achievement score in at least 6 standards (Content Standards, Graduate Competence Standards, Process Standards, Educator and Educational Personnel Standards, Management Standards, and Assessment Standards) showing proper result. It confirms Rachmawati and Daryanto (2013: 102) opinion that in assessing teacher performance, a supervisor must have the ability to: (1) understand the scope of the assessed variables, especially 
professional competence, (2) have standards in developing assessment instruments, (3) collect and analyze data, and (4) make judgments or final conclusions.

After Islamic education supervisor of elementary school did the evaluation, the result was reported to the teachers. Furthermore, joint evaluation was also conducted during the activity organized by Teacher Working Group of Islamic Education teacher of Elementary school in subdistrict level of Kota Magelang. Then, the supervisor proceeded to do follow-up activities such as coaching in which the teacher follows the guidelines and polishes his competencies. It confirms Hosnan (2016: 278) that teacher performance assessments are expected to demonstrate appropriately what activities the teacher should do in the classroom and help teachers improve their knowledge and skills. Therefore, it is expected that the teacher is continuously trying to improve their ability and competence in teaching and learning activities after getting the follow-up assessment from the supervisor.

\section{Islamic Education Teachers Performance}

In delivering teaching materials, a teacher should use appropriate teaching methods in order to achieve learning objectives. Moreover, they have to use various teaching methods in teaching students. Ginting (2014: 43) states that "teaching methods that teachers can use are numerous in which basic teaching methods include lecturing methods, question and answer methods, discussion methods, demonstration methods, role playing 


\section{Mudarrisa: Jurnal Kajian Pendidikan Islam, Vol. 10, No. 1, 2018}

methods, and practice teaching methods". The result showed that there were only 7 teachers mastered various teaching method, while another 28 teachers mastered some of them. Dealing with the teaching method mastered by teachers, 11 teachers answered only mastering the basic method including lecturing, discussion, questioning, giving assignment, demonstarting, and practicing, while 24 teachers mastered some development of teaching methods such as make a match, peer-teaching, warung ilmu, problem solving, Quis Jeo Pardi, Roll play, Talking stick, mind map, number together, crossword puzzle, interactive lecture, jigsaw, and shortcard. It shows that more than $50 \%$ teachers have mastered various teaching methods.

Teaching methods mastered by teachers can be obtained through participation in coaching activities conducted by supervisors. Dealing with teachers' participation in joining coaching workshop about teaching method, 33 teachers claimed that they have followed the coaching workshop in the form of bimbingan teknis (bimtek) which has been held 3 times in Kota Magelang, while only 2 teachers said never as they had not been long time becoming a teacher. It shows the teachers' activeness in following coaching workshop. Moreover, relating to the coaching done by school supervision, 35 teachers stated that the supervisor once held a coaching. Furthermore, dealing with the supervisors' intensity in conducting coaching, 16 teachers said supervisors do coaching every month when Teachers Working Group held in the sub-district, while 19 teachers stated that coaching was held once in 3 months by supervisor. 


\section{Mudarrisa: Jurnal Kajian Pendidikan Islam, Vol. 10, No. 1, 2018}

This statement is in line with the supervisors' statement who stated that the supervisors regularly conduct coaching every month and also in line with the observation by following the coaching through KKG activities.

Relating to the appropriate method, 32 teachers looked for appropriate answer after reading materials, while 3 teachers was based on the students' condition and grade. It confirms Suwardi (2007: 62) opinion on how educators in choosing teaching methods should pay attention to the following things: (1) the purpose of education; (2) the ability of educators; (3) the needs of learners; (4) the content or the learning materials. It shows that it is necessary to consider the above things in teaching methods.

Based on the method used in delivering Islamic education materials, 28 teachers stated that they have not delivered materials using teaching methods such as Short card, TTS, Jigsaw, Jeo Pardi, mind map, talking stick, simulation, demonstration and chain message, while 7 teachers used the basic method. This is in line with the opinion Vienna Sanjaya in Gunawan (2013: 180) which states that Islamic education teacher of elementary school can use teaching methods including discussion, demonstration, and simulation. Relating to the application of developed teaching method, 26 teachers applied developed teaching method by following changes, while 9 teachers stated they had not applied and still used the basic one. It is in line with Huda (2014: 204) that there are many methods combining or modifying the basic methods such as jigsaw, Talking Stick, Snowball Throwing, Make A Match and another method. Therefore, a 
teacher is expected to be able to use the combination of teaching methods or at least try to use them.

Moreover, relating to the facilities, 30 teachers stated that the facilities was very complete, including places of worship, LCD, media, letter boxes, tapes, CDs, and modules that were used for teaching, while 5 teachers declared incomplete. This showed that most of elementary schools in Magelang already had facilities to support teaching and learning process, so actually there was no good reason for teachers who had not been willing to apply various developing methods of learning.

Dealing with learning objectives achievements when Islamic education teachers apply teaching method, 21 teachers stated that $80 \%$ of learning objectives can be achieved, while 14 teachers argued that the achievement was below $75 \%$. Furthermore, the result also showed that 33 teachers stated the student loved the method, while 2 teacers said only some students liked it. This mapped out that delivering materials using varied teaching methods made them love Islamic education materials, so the learning objectives can be achieved.

In conducting evaluation towards the teaching method, 33 teachers said they did evaluation, while the other 2 did not do it. Moreover, as 35 teachers stated they continued developing the methods when it was succeded, it shows that they did not give up easily in implementing teaching method for achieving learning objectives. 


\section{CONCLUSION}

Islamic education teachers of elementary school coaching have been conducted by the supervisors in Kota Magelang with appropriate steps. In conducting coaching, the supervisors create annual program, semester program, and Academic Activity Plan (RKA) in advance. They carried out coaching regularly every month through $\mathrm{KKG}$ followed by all Islamic Education teachers of elementary school in Kota Magelang.

The supervisors assessed teachers' performance gradually starting with creating as well as implementing teachers performance assessment listed in annual program, semester program, and Academic Activity Plan (RKA), examining the implementation of teachers performance assessment report, and forming follow-up plan for teachers performance assessment. Teachers Performance Assessment was conducted routinely through academic supervision referring to programs that met the government standard. The assessment was done once in a semester in the target school and reported once a year in the form of score. Based on the assessment result, the supervisors' evaluation for conducting coaching was made.

In implementing teaching methods, the Islamic education teachers had applied various teaching method including make a match, peerteaching, warung ilmu, problem solving, Quis Jeo Pardi, Roll play, Talking stick, mind map, number together, crossword puzzle, interactif lecture, jigsaw, and shortcard. Furthermore, the Islamic Education teachers of elementary school in Kota Magelang also had used the developing learning methods. 


\section{REFERENCES}

Arikunto, S. \& Lia, Y. (2012). Manajemen Pendidikan. Yogyakarta: Aditya Media.

Creswell, J.W. (2010). Research Design Pendekatan Kualitatif, Kuantitatif, dan Mixed. Yogyakarta: Pustaka Pelajar.

Daryanto. (2013). Standard Kompetensi dan Penilaian Kinerja Guru Profesional. Yogyakarta: Penerbit Gava Media.

Dunst, C.L. Raab, M. Hamby, D.W (2017). Contrasting approaches to the response-contingent learning of young children with significant delays and their social-emotional consequences. Research in Developmental Disabilities 63 (2017) 67-73

Gintings, A. (2014). Esensi Praktis Belajar dan Pembelajaran. Bandung: Humaniora.

Glickman, C. D., Stephen, P. G., Jovita M., \& Ross, G. (2009). The Basic Guide to Supervision and Instructional Leadership, Second Edition. Boston: Pearson.

Gunawan, H. (2013). Kurikulum dan Pembelajaran Pendidikan Agama Islam. Bandung: Penerbit Alfabeta.

Huda, M. (2014). Model-model Pengajaran dan Pembelajaran (Isu-isu Metodis dan Paradigmatis. Yogyakarta: Pustaka Pelajar.

Hosnan, M. (2016). Etika Profesi Pendidik Pembinaan dan Pemantapan Kinerja Guru, Kepala Sekolah, serta Pengawas Sekolah. Bogor: Penerbit Ghalia Indonesia.

Mulyasa. (2006). Menjadi Guru Profesional Menciptakan Pembelajaran Kreatif dan Menyenangkan. Bandung: PT. Remaja Rosdakarya.

Rachmawati, T. \& Daryanto. (2013). Penilaian Kinerja Guru Profesi Guru dan Angka Kreditnya. Yogyakarta: Penerbit Gava Media.

Sanjaya, W. (2010). Strategi Pembelajaran Berorientasi Standar Proses Pendidikan. Jakarta: Prenada Media Group.

Sugiyono. (2014). Metode Penelitian Pendidikan (Pendekatan Kuantitatif, Kualitatif, dan REDD). Bandung: Alfabeta.

Suhardan, D. (2014). Supervisi Profesional. Layanan dalam Meningkatkan Mutu Pembelajaran di Era Otonomi Daerah. Bandung: Alfabeta. 
Mudarrisa: Jurnal Kajian Pendidikan Islam, Vol. 10, No. 1, 2018

Suwardi. (2007). Manajemen Pembelajaran Mencipta Guru Kreatif dan Berkompetensi. Salatiga: STAIN Salatiga Press.

Suwardi, Anitah, W. S., Akhyar, M. \& Asrowi. (2017). Gender Bias in Islamic Textbooks for Muslim Children in Indonesia. Attarbiyah: Journal of Islamic Culture and Education. 2 (2). 214 - 235.

Suwardi, Anitah, W. S., Akhyar, M. \& Asrowi. (2017). The Relevance Of Pictures As Media In Thematic Learning Book With Pluralism Values In Indonesia. International Journal of Law, Government and Communication (IJLGC). 2 (6). 01-08.

Thomas, S. \& Starratt, R. (1993). Supervision A Redefinition. New York: Mc Graw Hill.

Zepeda, S.J. (2003). Instructional Supervision Applying Tools and Concept. New York: Richard H. Adin Freelance Editorial Services. 